\title{
2008 年岩手·宮城内陸地震の被害と地盤の永久変位の関係
}

\author{
神山 眞 ${ }^{1)}$ 、松川忠司 ${ }^{2)}$ 、穴澤正宏 ${ }^{3)}$ \\ 1) 正会員 東北工業大学、教授 工博 \\ e-mail : mkamiyam@tohtech.ac.jp \\ 2) 東北工業大学、助手 \\ e-mail : matukawa@tohtech.ac.jp \\ 3) 東北工業大学、准教授、理博 \\ e-mail : anazawa@tohtech.ac.jp
}

\begin{abstract}
要 約
本文は国土地理院が運営するGPS技術による地殼変動観測システムGEONETにより求めら れた2008年岩手・宮城内陸地震の際に生じた地盤の永久変位と同地震による被害分布との 関係を考察したものである。2008年岩手・宮城内陸地震では4学協会合同調査委員会により 各種構造物の被害がGISシステムとしてまとめられている。ここでは、GEONETによる水平、 鉛直の両方向の地盤永久変位、強震記録による震度の分布が被害分布と比較され、同地震 で顕著であった斜面被害は地盤永久変位の分布とより強い相関があることが指摘される。
\end{abstract}

キーワード：2008年岩手・宮城内陸地震、GEONET、GPS、永久変位、被害

\section{1. はじめに}

2008年6月14日8時43分ごろ、岩手県内陸南部を震源とする平成20年（2008年）岩手・宮城内陸地震 （M7.2）が発生した。この地震により、岩手県奥州市と宮城県栗原市で震度6強、宮城県大崎市で震度6 弱を観測したほか、北海道から中部地方にかけて摇れを感じた。この地震は深さ約 $8 \mathrm{~km}$ 震源とした西 北西一東南東の圧縮軸をもつ逆断層型であり、近年我が国で発生した逆断層型の内陸地震としては最大 規模のものであることが明らかにされている ${ }^{1) 。}$

この地震により死者・行方不明者 23 名、負傷者 431 名（平成20年6月30日現在）の人的被害がもたらさ れたほか、住家被害、道路施設被害（路床路盤、橋、トンネルなど）、河川施設被害、上下水道などの ライフライン施設被害、農業施設被害など多くの施設構造物が被災した。とりわけ、震源域が多様な火 山性堆積物を有する山間部にあることを反映して、大規模な土砂災害（崖くずれ、地すべり、土石流な ど）が発生して、道路不通、集落の孤立、河道の閉塞など中山間地特有の被害形態が現れている。

この地震は内陸直下の地震としていくつかの特徵を有している。一つは、地震の規模が内陸地震とし て最大規模であるにも関わらず、かつ強震観測歴史上の最大の加速度（3成分合成で約4000ガル）を記録 した地震であるにも関わらず、被害が地域、規模、形態などの上から限定されていることである。二つ には、震源近傍での強震記録を始め、GPSによる地款変動などの各種のデータが震源域から遠地にわた り広範囲、高密度で得られていることである。三つは、上記の各種の被害位置が地震後発足した平成20 年岩手・宮城内陸地震4学協会東北合同調査員会 ${ }^{2)}$ によりGISシステムとして詳しく明らかにされている ことである。これらの特徵は地震被害の原因と結果の因果関係を考察する上で格好の材料を提供してい 
るものと考えられる。

本論文は上記の 2008 年岩手・宮城内陸地震の特徵に鑑み、同地震による被害箇所と各種の強震動デー タとの相関を考察したものである。特に、国土地理院が展開するGPS技術利用による地殼変動観測ネッ トワークGEONETによるデータはこれまで地震予知の観点から注目されてきているものの、地震被害の 原因などの工学的な利活用については十分な検討がなされているとは言えない中、今回の地震において は震源近傍を中心に詳細な地盤の永久変位データを与えている。GEONETは近年 1 秒ごとのリアルタイ ムのデータ提供を行っており、正確な座標位置の情報から迅速な地盤の永久変位の把握が可能であり、 広範な地震工学への応用が考えられる。本論文はGEONET データの工学的な利活用を検討する観点か ら、2008年岩手・宮城内陸地震における被害分布とGEONETによる地盤の永久変位の関係について中心 的に考察している。

\section{2008年岩手・宮城内陸地震における強震観測データと被害分布の整理}

2008年岩手・宮城内陸地震では内陸で生じた規模の大きな地震の特徵を反映して震源近傍から遠距離 にわたって各種機関により多くの強震記録が得られている。図1は震源近傍で強震記録を得た観測点の分 布を示したものである。これらの観測点は（独）防災科学研究所によるK-NETおよびKiK-net観測点、気 象庁JMAの震度観測点（岩手県、宮城県、秋田県、山形県の震度情報ネットワークの震度観測点を含む） である。図1では気象庁発表の震央ならびに気象庁、（独）防災科学研究所、各大学などのデータを一元 的に処理して得られた本震後一ヶ月以内に生じた余震 ${ }^{4)}$ の分布もプロットされている。図1において県 の行政区画線が鎖線で、また標高もカラーイメージの分布として与えられているが、4県にまたがり各種 の地盤条件で万遍に密度よく観測点が分布していることがわかる。図2にこれらの観測点で得られた強震 記録の例として震央距離 $2.7 \mathrm{~km}$ に位置する KiK-net一八関西観測点の地表で得られた 3 成分加速度記録 ${ }^{5}$ を示す。規模の大きな内陸地震の震源近傍の記録を反映して極めて大きな加速度振幅を有している。こ のような各観測点の記録を用いて最大加速度、最大速度、最大変位、気象庁方式の計測震度などの各種 の地震動パラメータの分布を求めた。図3および図4はこれらのうち最大加速度値、計測震度の分布を示

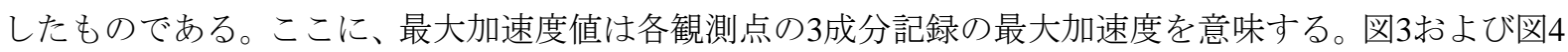

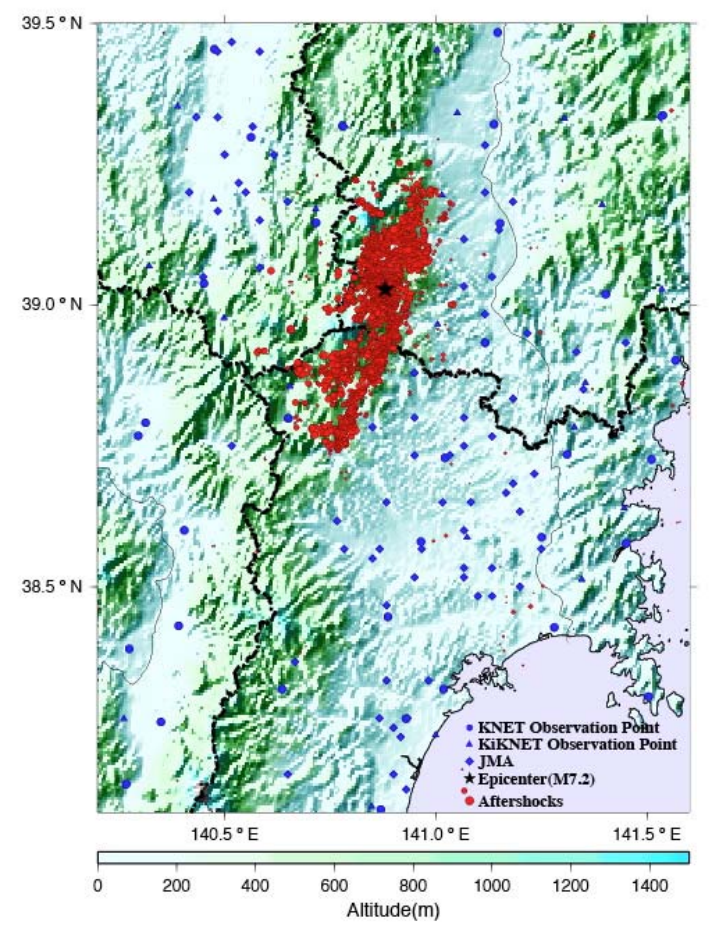

図1＼cjkstart強震観測点の分布

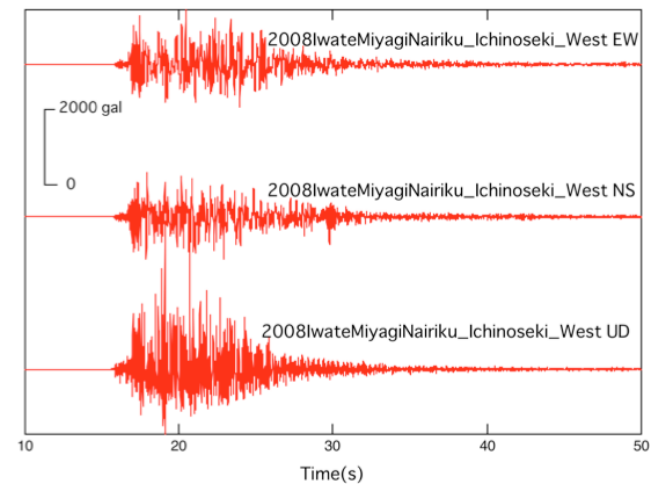

図2ＫiK-net一関西観測点の加速度記録 
ではそれぞれの值の分布がカラーイメージで与えられるとともに、先に述べた一元化処理による余震分 布と標高分布が参考のためプロットされている。図3の最大加速度值の分布では大きな加速度值が震央中 心に集中して分布して、余震分布と比較的相似している状況がみられる。一方、計測震度分布では震央 付近に加えて、余震発生のみられない大崎平野に大きな震度が分布するなど、震源の他、ローカルサイ 卜効果が影響を与えている様相がみられる。

以上のように 2008 年岩手・宮城内陸地震では強震動分布が詳しく明らかにされているが、このような 分布は被害と相関を有していると予想される。同地震では地震発生後1ヶ月を経て、4学協会から構成さ れる合同調查委員会が発足した。この委員会は被害の実態を後世に残すことを主たる目的に掲げ、約1 年にわたる調査活動を行い、調査報告書を発行した ${ }^{2)}$ 。同報告書は調査データを素直に残すことを重視 して編成されている。すなわち、被害内容と被害位置との関係を詳述するため、紙媒体としての記述法 に加えて、GIS技術を駆使して、電子媒体として被害状況を表現することに意が用いられている。この ようなことから同報告書では通常の紙媒体による取りまとめに加えて、DVD媒体として被害情報のマッ ピング処理が付属資料として添付されている。これらの被害情報はつぎのような各種の構造物ごとに整 理されている。

(1) 土木関係施設の被害（橋梁、トンネル、高速道路、鉄道、河道閉塞、堤防、ダム、農業施設、造成地 など)

(2) 地震に伴う地表変状

(3) 斜面変動（深層地す心゙り、浅層崩壊、崩壊性地す心゙り、土石流）

(4) 河川閉塞

土木関係施設の被害は同報告書およびDVD媒体にマッピング処理のデータとして「3.4地震災害GIS の登録情報」にまとめられている。これらの被害内容を表1に示す。表1に示すように、ここでの土木関 係施設被害は何らかの土木工事の施工された施設の被害である。一方、同報告書およびDVDでは同地震 の特徴が多くの斜面被害をもたらしたことから上記(2)、(3)、(4)の被害を自然斜面の被害として「4.1 被 災地域での斜面変動のタイプと分布および特徵」にまとめている。これらは空中写真判読により求めら

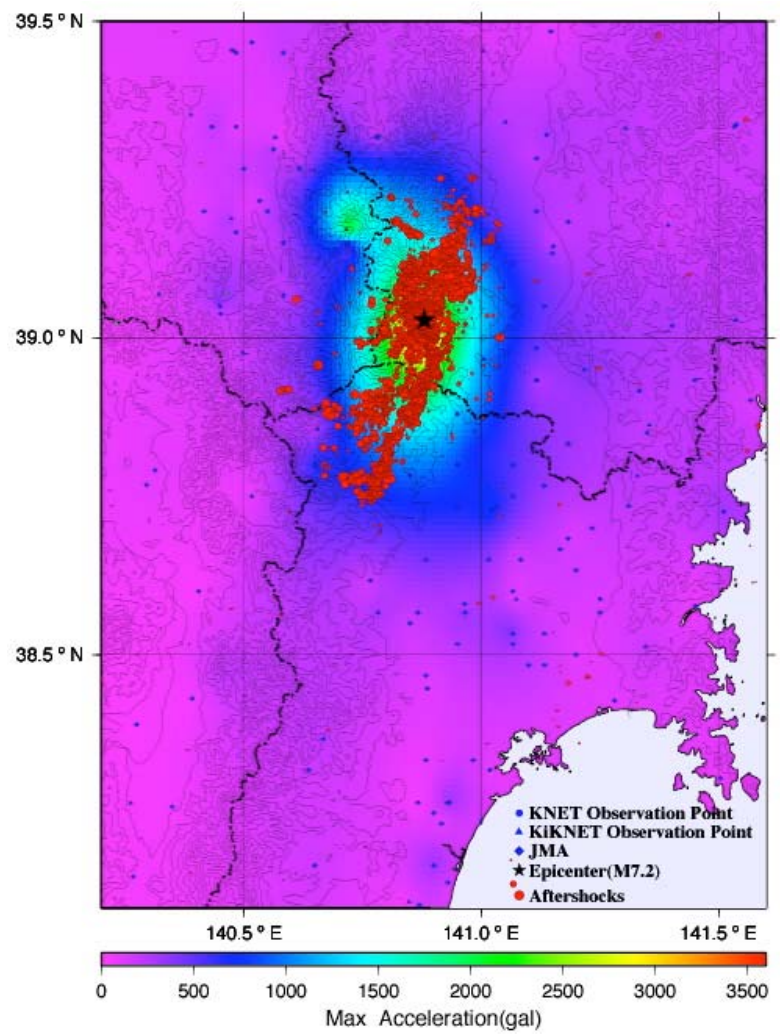

図3 最大加速度值の分布

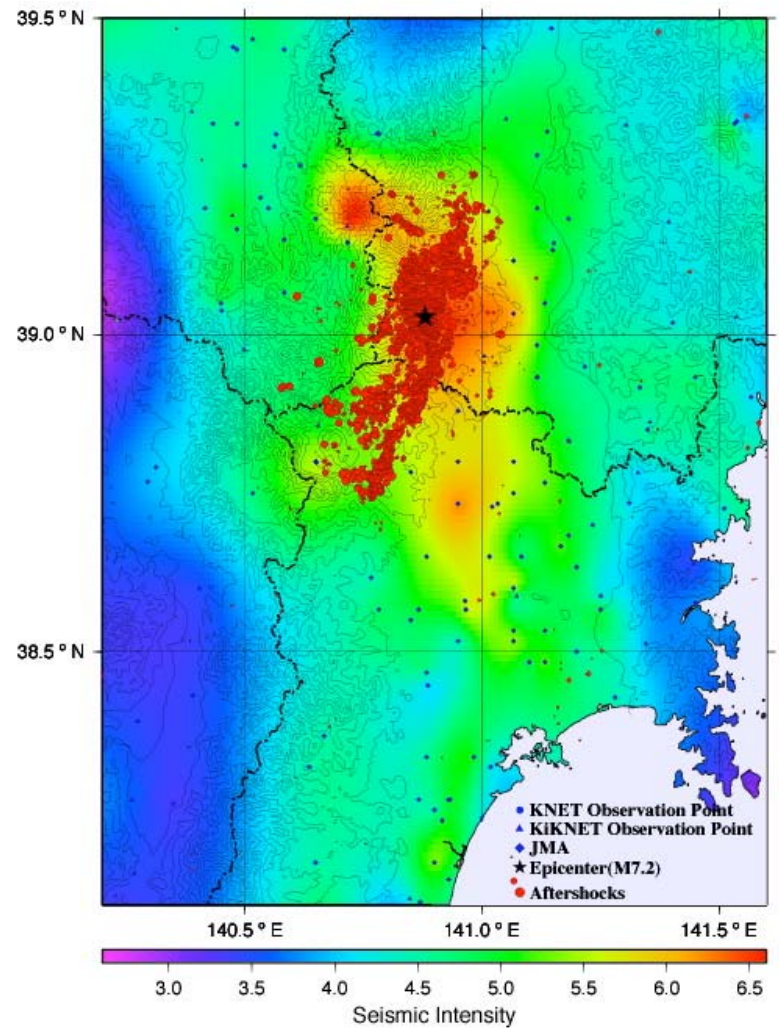

図4＼cjkstart計測震度の分布 
表1土木関係施設被害データー覧

各県轄施設被害

\begin{tabular}{|c|c|c|c|c|c|}
\hline 県 & 公共土木施設 & 農地·農業用施設 & 林道 & 治山 & 合計 \\
\hline 岩手県 & 314 & 142 & 22 & 71 & 549 \\
\hline 宮城県 & 304 & 78 & 11 & 46 & 439 \\
\hline 秋田県 & 113 & 0 & 8 & 1 & 122 \\
\hline 計 & 731 & 220 & 41 & 118 & 1,110 \\
\hline
\end{tabular}

国交省直轄施設被害

\begin{tabular}{|c|c|c|c|c|c|}
\hline & 道路 & 河川 & 砂防 & ダム & 合計 \\
\hline 国交省 & 4 & 5 & 6 & 2 & 17 \\
\hline
\end{tabular}

れており、地点箇所が同報告書の 4.1 章に地図としてプロットされている。また、具体的な座標はDVD のGISに整理されている。なお、これらの11土木関係施設の被害および(2)、(3)、(4)の被害箇所は、最近、 GIS として「とうほく地盤情報システム運営協議会」による地盤情報サイト「みちのくGIDAS」 ${ }^{3)}$ に掲 載されている。

図 5 はこれらの被害のうち上記(1)の土木関係施設の被害箇所をプロットしたものである（以下、土木 関係施設の被害）。図5では全部で1144箇所の被害点がプロットされている。一方、図6は上記(2)、(3)、 (4)の被害箇所、すなわち河川閉塞の箇所を含めて何らかの自然斜面変動の被害があった箇所をプロット したものである（以下、斜面被害）。図6では全部で2131箇所の被害点がプロットされている。図5、図6 ともに震央の位置が与えられるとともに、標高コンターが薄い実線で、県の行政境界が濃い実線で記さ れている。なお、図5と図6では被害箇所の判定出典は異なるが、前者には土木施工した斜面の被害箇所 が含まれており、自然斜面を空中写真から判読した後者の被害箇所と重複している可能性がある。ここ では重複の識別が困難であることから、被害報告書により分類された原データをそのまま利用している。

図5、図6をみると土木関連施設の被害箇所が震央に対して南部領域で多くなっているものの震央周り に均等に分布する傾向を有しているのに対して、斜面被害箇所は震央の南部領域に圧倒的に多く偏在す る傾向を有していることがわかる。これらの分布と図4の計測震度などの強震動分布との比較は後章で詳 しく考察されるが、一見した比較でも土木関連施設の被害箇所は計測震度分布と整合しているのに対し て、斜面被害箇所は相関が相対的に低いことがわかる。なお、2008年岩手・宮城内陸地震の震源近傍の 地盤、地質については4学協会合同調查委員会の報告書に詳しく考察されているが、これらの考察を参照 しても震央の南部領域が北部領域に比して大幅に異なる地盤・地質の特性を有していることは考えられ ない。したがって、斜面被害に関する特徴的な分布は地盤・地質の種別とは別の観点からの考察が必要

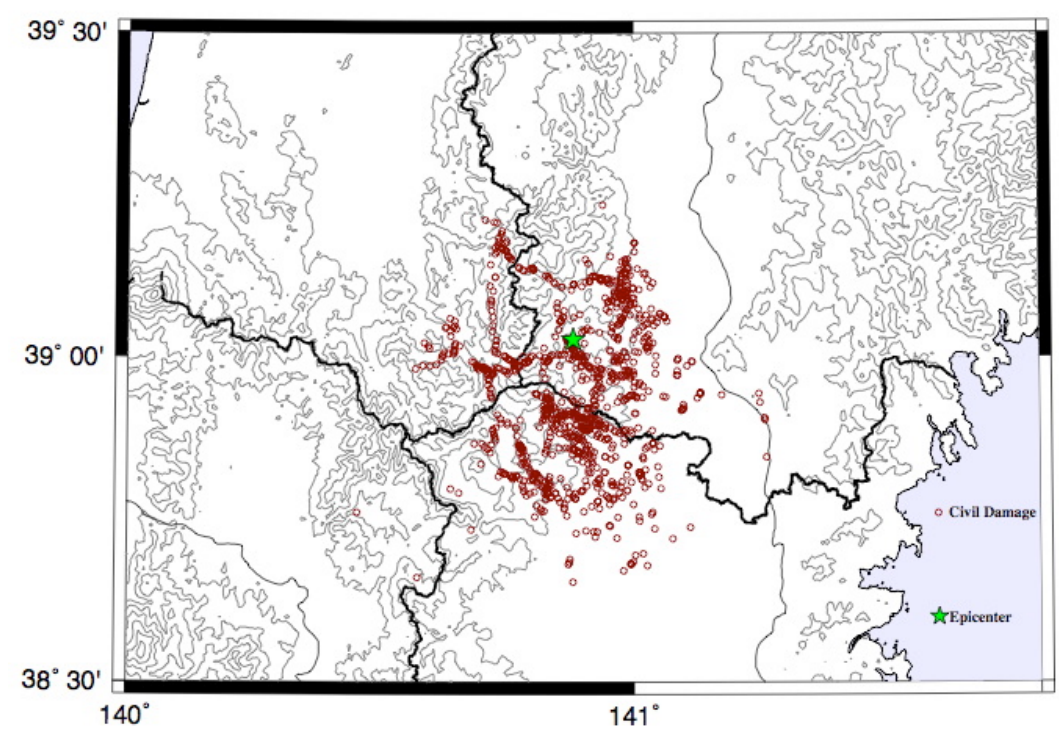

図5 土木関連施設の被害箇所分布 


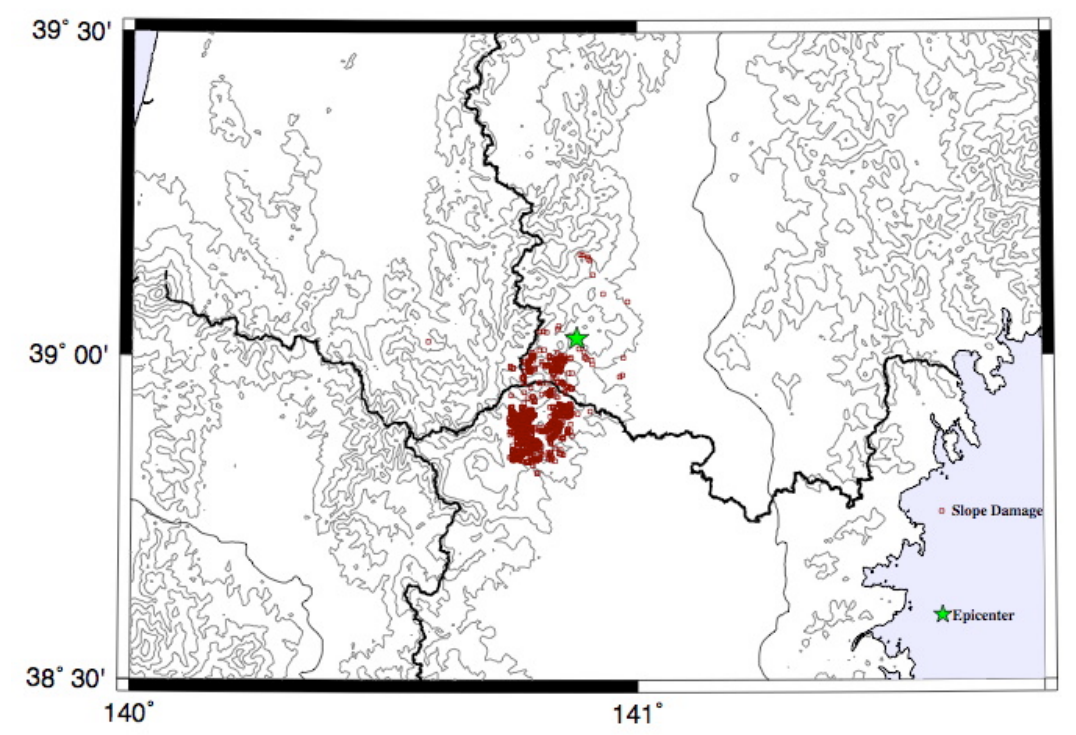

図6 斜面被害の被害箇所分布

と考えられる。この観点から本研究では強震記録による強震動特性とは異なる要因としてGEONETによ る地款変動、すなわち地盤の永久変位に着目した。

\section{GEONETとその取得データについて}

1995年兵庫県南部地震の被害経験から政府は地震に関する基盤的調查観測計画を強力に推進している。 これに基づき、強震観測システムK-NET、KiK-net、高感度地震観測システムHi-net、広帯域地震観測シ ステムF-net、高密度陸域地殼変動観測システムGEONETなどの国家的な観測プロジェクトが構築されて いる。これらの基盤的調査観測のうち、GEONETの地震工学の分野での利活用の例は相対的に少ない。

上述した政府の「地震に関する観測、測量、調査及び研究」の基本施策を受けて、国土地理院 ${ }^{6)}$ は日 本全国に約1、200点のGPS位置観測点（電子基準点）を整備し、データの収集及び解析処理を行い、日 本列島の位置情報を日々管理・監視している。当然のことながら、位置情報の連続的なデータは地点の 変動、寸なわち変位の直接的な情報を与えることから、地震前後に生じる地殼変動を教えるものであり、 地震予知にとっても、地震被害の調査などでも必須欠くべからざる情報である。従来、このような変動 は三角測量等の地道な文字通り地を這う観測によって達成されてきたものであるが、近年のGPS技術は 驚くべき精度で位置情報の取得を可能にした。このGPSシステムを本格的に利用した測地システムが GEONETといえる。GEONET(GPS Earth Observation Network)とは、このような測地の対象点のネットワ ークである電子基準点網と解析処理部分を併せたシステム全体を指寸ものである。GEONET全体のシ ステム構成は年々充実が図られ、2008年4月現在の観測点数は全国1238点となっている ${ }^{6)}$ 。

GEONETのデータは用途に応じた 3 種類の精度をもったデジタルデータとして公開されている。筆者 らは1996年以来公開されているGEONETデータのうち電子基準点の観測データ・最終解析(F 3 )の結果

（日々の座標値）を用いて2000年以来発生した被害地震による永久変位を算定している。ここでは内陸 直下の規模の大きな地震の事例として2008年岩手・宮城内陸地震の結果について詳細に述べる。

図7は2008年岩手・宮城内陸地震の震源付近でのGEONET観測点分布を標高分布図とともにプロット したものである。図7に示すように震央を囲みほぼ均等に配置されている。これらの観測点は2008年6月 14日午前8時43分頃に発生した2008年岩手・宮城内陸地震の前後の位置情報を正確に記録している。図8 は震源に最も近いGEONET観測点・栗駒2における地震発生年を含めた過去6年にわたる毎日 12 時00分の 位置情報（北緯、東経、標高の各值）の時系列変動を示したものである。地震の発生した6月14日午前8 時43分頃を挟む前日6月13日12時00分と当日6月14日12時00分で大きく変動していることがわかる。この ような位置の変動情報から永久変位を算定することが可能である。日々の位置情報は各種の原因で微小 


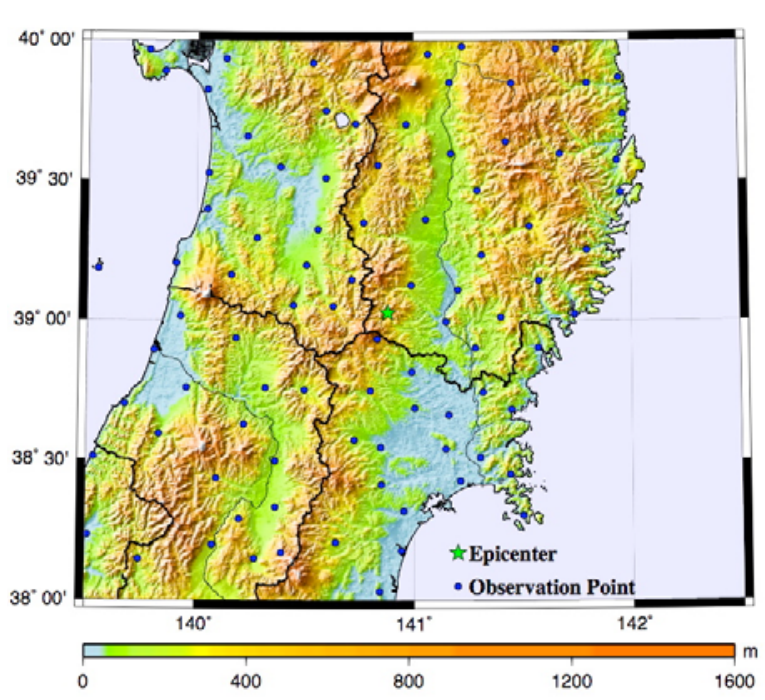

図7 GEONET観測点の分布
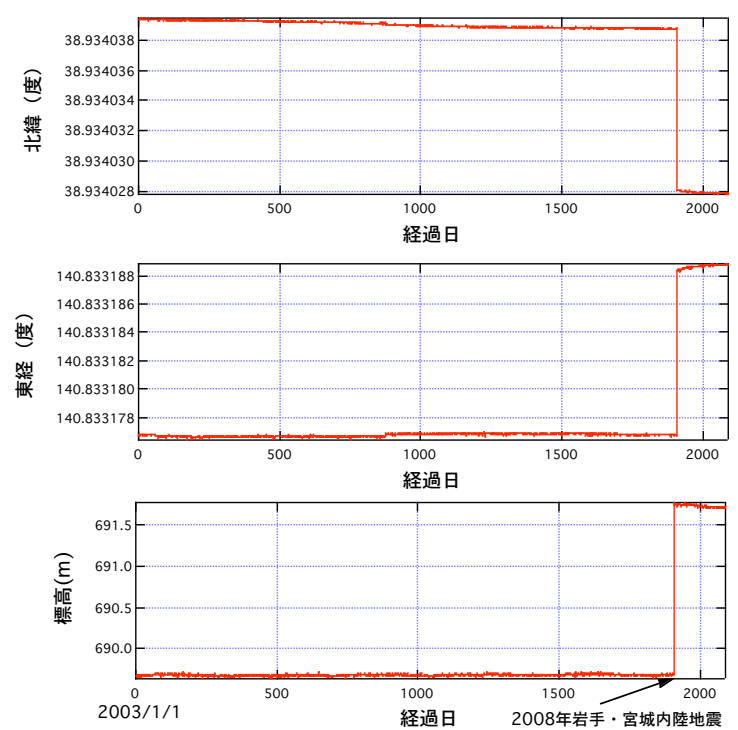

図8＼cjkstart栗駒2における日々座標の時系列変動

\section{表2＼cjkstart代表的観測点における永久変位の値}

\begin{tabular}{|c|c|c|c|c|c|c|}
\hline 観測点ID & 観測点名 & 東経 $\left(^{\circ}\right)$ & 北緯 $\left.^{\circ}{ }^{\circ}\right)$ & 東西変位(m) & 北南変位(m) & 上下変位 $(\mathrm{m})$ \\
\hline 20913 & KURIKOMA2 & 140.833 & 38.934 & 0.949 & -1.174 & 2.083 \\
\hline 950193 & MINASE & 140.630 & 39.052 & 0.273 & -0.088 & -0.019 \\
\hline 20928 & HIGASHINAR & 140.715 & 39.146 & 0.201 & -0.132 & -0.012 \\
\hline 950173 & KURIKOMA & 140.991 & 38.815 & -0.151 & 0.122 & -0.016 \\
\hline 20912 & HIRAIZUMI & 141.149 & 38.995 & -0.147 & 0.032 & -0.014 \\
\hline 940029 & MIZUSAWA1 & 141.204 & 39.111 & -0.086 & 0.047 & 0.020 \\
\hline 20929 & OGACHI & 140.447 & 39.054 & 0.094 & -0.023 & 0.002 \\
\hline 960554 & YUZAWA & 140.507 & 39.199 & 0.072 & -0.043 & -0.001 \\
\hline 51145 & INATEKAWAS & 141.283 & 38.902 & -0.075 & 0.021 & -0.001 \\
\hline 950174 & NARUKO & 140.802 & 38.749 & -0.028 & 0.014 & -0.051 \\
\hline 20915 & TAKASHIMIZ & 141.004 & 38.686 & -0.044 & 0.038 & -0.010 \\
\hline 20911 & INATEDAITO & 141.401 & 39.012 & -0.048 & 0.006 & -0.006 \\
\hline 20914 & MIYAGITOUW & 141.318 & 38.743 & -0.043 & 0.016 & -0.010 \\
\hline 950200 & FUKUSHIMA & 140.466 & 37.683 & -0.008 & -0.007 & -0.046 \\
\hline 20938 & FUKUSHIMAT & 140.572 & 37.591 & -0.002 & -0.011 & -0.045 \\
\hline 950190 & YOKOTE & 140.560 & 39.327 & 0.036 & -0.027 & -0.003 \\
\hline 970796 & ISAWA & 140.988 & 39.127 & -0.016 & 0.025 & -0.033 \\
\hline 20916 & MINAMIKATA & 141.161 & 38.661 & -0.030 & 0.023 & -0.004 \\
\hline 960560 & NIHONMATSU & 140.373 & 37.621 & 0.036 & 0.000 & -0.013 \\
\hline 950192 & CHOUKAI & 140.162 & 39.164 & 0.033 & -0.013 & 0.002 \\
\hline
\end{tabular}

な変動をすることから永久変位の算定には種々の方法が考えられるが、ここでは各観測点の地震前の変 動を調べた結果、それらの変動は地震を挟む変動に比し少ないことから、ここでは単純に同地震発生日 の前日と当日の 12 時 00 分の位置情報の差から東西、南北、上下方向の3成分における永久変位を求めた。 表2は算定された永久変位の大きな上位20観測点における算定結果をまとめたものである。ここで、東経、 北緯は地震前の位置を意味して、東西方向の変位は東方向をプラス、北南方向の変位は北方向をプラス、 上下方向の変位は上方向をプラスとして与えられている。最大の変位は震央に最も近い観測点の栗駒 2

（KURIKOMA2、震央距離約 $11 \mathrm{~km}$ ) において東西方向で $0.949 \mathrm{~m}$ 、北南方向で $-1.174 \mathrm{~m}$ 、上下方向で $2.083 \mathrm{~m}$ と算定されている。

以上のような各観測点における永久変位の分布を水平方向、上下方向のそれぞれのベクトル值をもっ てプロットしたのが図9および図10である。永久変位ベクトル值をそのままの值でプロットすると数的 ら数mmのオーダーで変動する各観測点の広域的な変位ベクトルを識別できないことから、図9および図 10では若干の工夫を加えてベクトルをプロットしている。すなわち、もとのベクトル值をmm単位に変

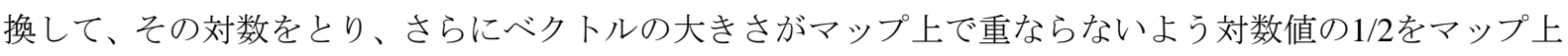
の単位の值として、これを基準にプロットしてある。さらに、図9および図10でベクトルの大きさの等 
值線が与えられるとともに、震央、先に述べた余震分布、標高のコンター、県境界なども参考にプロッ 卜されている。図9および図10から我々は多くのことを知ることができる。一つは、この地震により日本 列島が震源断層を挟んでほぼ東西方向に短縮している事実である。これは図9の水平方向のベクトル分布 から明瞭に把握できる。水平方向の永久変位は太平洋岸から日本海岸まで及んでおり、震源断層を挟ん で逆方向で明確に震源断層の方向に向いている。また、水平方向における変位べクトルの大きさの等值 線は震源断層を挟んで両脇に伸びる慓篂形の極めて特徵的な分布を示している。一方、図10の上下方向 の永久変位分布から、水平方向と上下方向では全く異なる変位分布パターンが存在することがわかる。

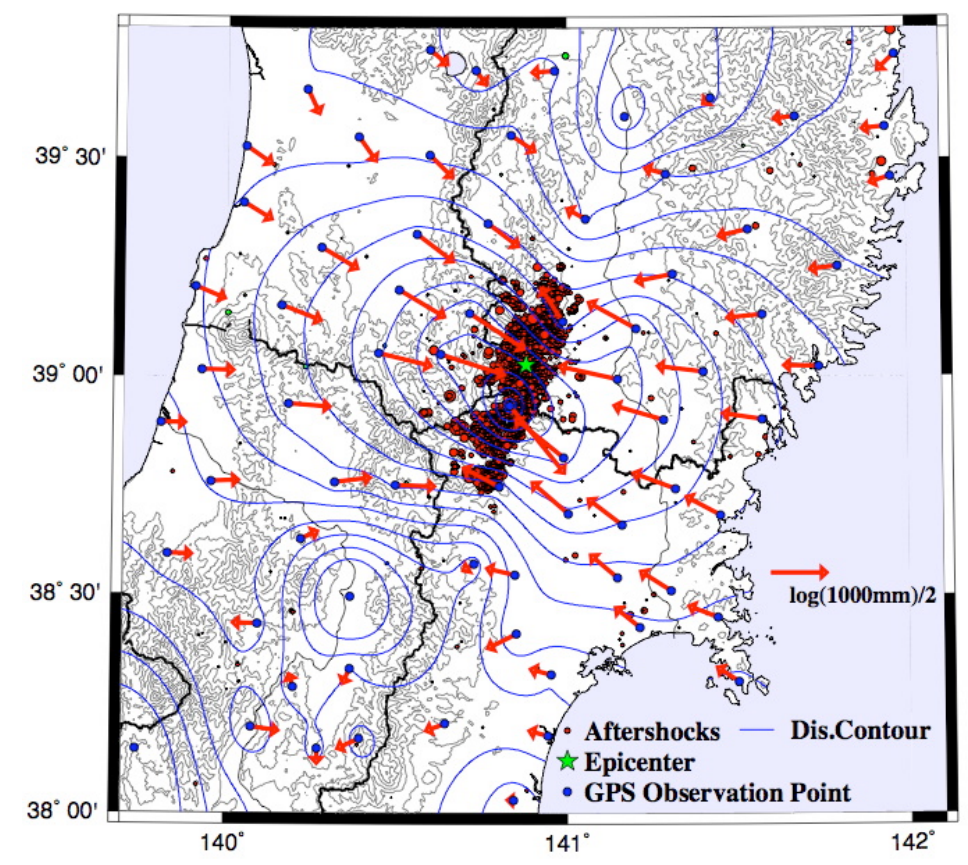

図9＼cjkstart水平方向の永久変位ベクトル分布

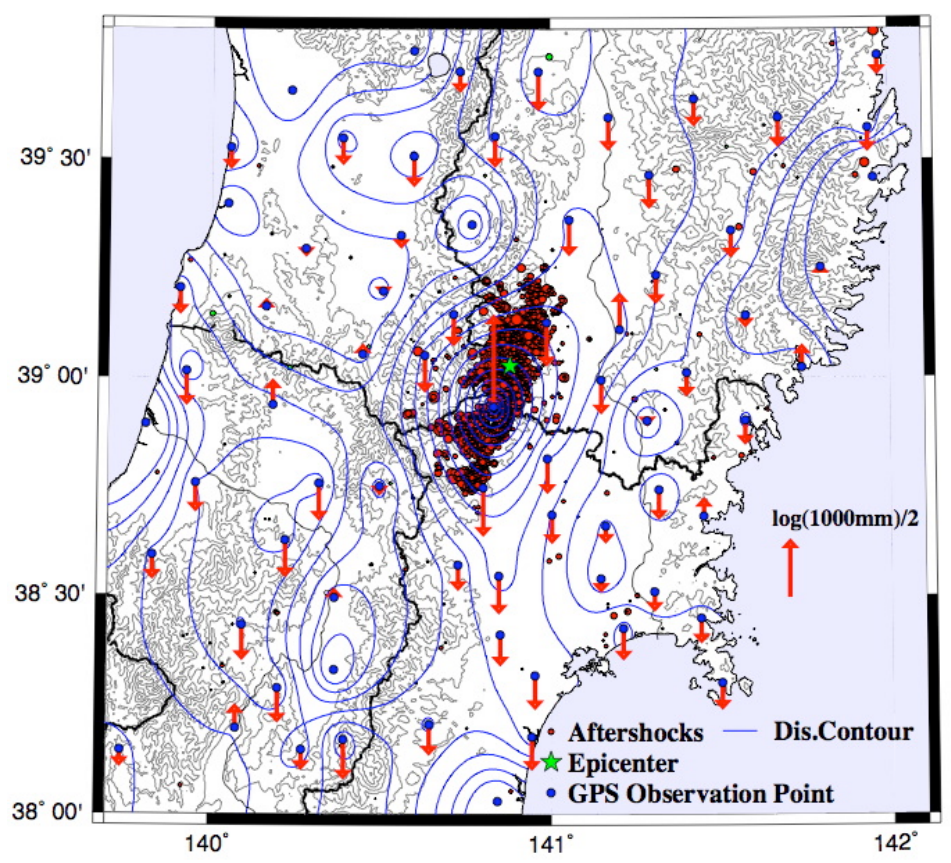

図10上下方向の永久変位ベクトル分布 
上下方向の永久変位分布から震源近傍を除き、広く地盤が沈下する永久変位が上下方向に生じたこと、 その大きさの分布パターンは水平方向の変位分布と異なり、震源断層の水平面投影と相似形となる傾向 を示していることがわかる。これらの水平、上下の両方向の変形パターンは次章で述べるように逆断層 のパターンに符号している。

\section{4. 断層モデルによる永久変位の理論計算とGEONETデータとの比較}

上記のようにGEONETの観測データにより地盤の永久変位が求められたが、ここではこれらの観測デ ータの妥当性について震源断層モデルによる理論計算との比較の観点から検討する。

遠田ら ${ }^{7)}$ は均質半無限弾性体の食い違い理論を用いて断層による変形パターンを算定するディスロケ ーションソフトウエア「Coulomb」を開発して、フリーウェアとして公開している。一方、2008年岩手・ 宮城内陸地震の震源断層パラメータは遠地実体波記録を用いた逆解析により東京大学地震研究所・強震 動グループにより算定されている ${ }^{8)}$ 。本研究ではこれらの震源断層パラメータを参考にして、Coulomb により永久変位などを算定した。用いた震源断層パラメータを表3に示す。なお、Coulombにおける算定 点のグリッド間隔は東西、南北それぞれ $0.05^{\circ}$ とした。算定結果の永久変位分布の3次元俯瞰図を図 11 に示す。また、GEONETの観測データを整理した図9、図10に合わせて、Coulombによる水平方向、上下 方向の理論永久変位の分布図をそれぞれ図12、図13に示す。図9、図10の観測データによる永久変位分布 と図12、図13の理論による永久変位分布を比較すると、Coulombによる理論変位分布が震源断層面にお ける一様な食い違いを仮定したものであることから細部の分布傾向は異なるところがある。例えば、観 測データの変位分布は最大変位值が震央の南側に存在しているのに対して理論変位ではそのようになっ ていないなどの違いがみられる。ただ、大局的には観測データは震源断層による理論分布と整合してい ることが観察される。特に、水平方向の永久変位の分布における漂箪形の独特なパターンや上下方向の 断層形状に相似した分布パターンなどはCoulombの算定結果にも明瞭に再現されており、GEONETの観

表3 Coulombの計算に用いた震源断層パラメータ

\begin{tabular}{|c|c|c|c|c|}
\hline 震源 & $\mathrm{E} 140.88^{\circ}$ & $\mathrm{N} 39.028^{\circ}$ & 深さ $8 \mathrm{~km}$ & \multirow{2}{*}{ Mw6.8 } \\
\hline \multirow{2}{*}{ 断層 } & 長さ $44 \mathrm{~km}$ & 幅 $24 \mathrm{~km}$ & 食い違い $=2.5 \mathrm{~m}$ & \multirow{2}{*}{} \\
\cline { 2 - 4 } & 走向 $203^{\circ}$ & 傾斜角 $37^{\circ}$ & 食い違い方向 $93^{\circ}$ & \\
\hline
\end{tabular}

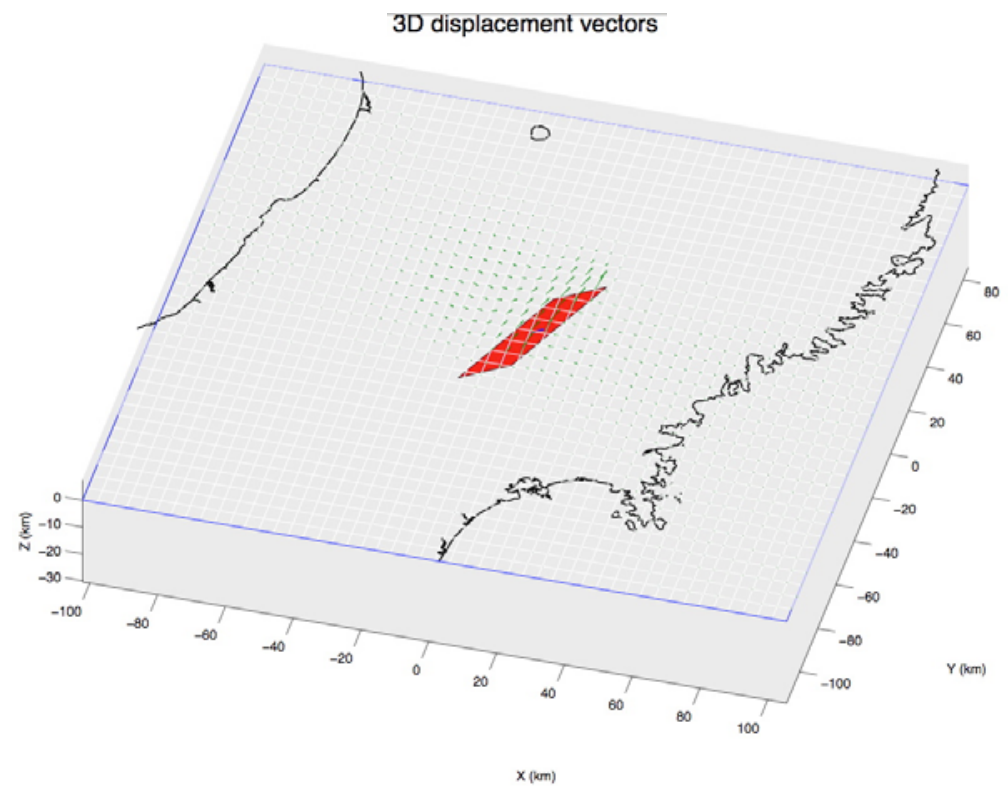

図11 Coulombにより算定された理論永久変位の3次元俯瞰図 


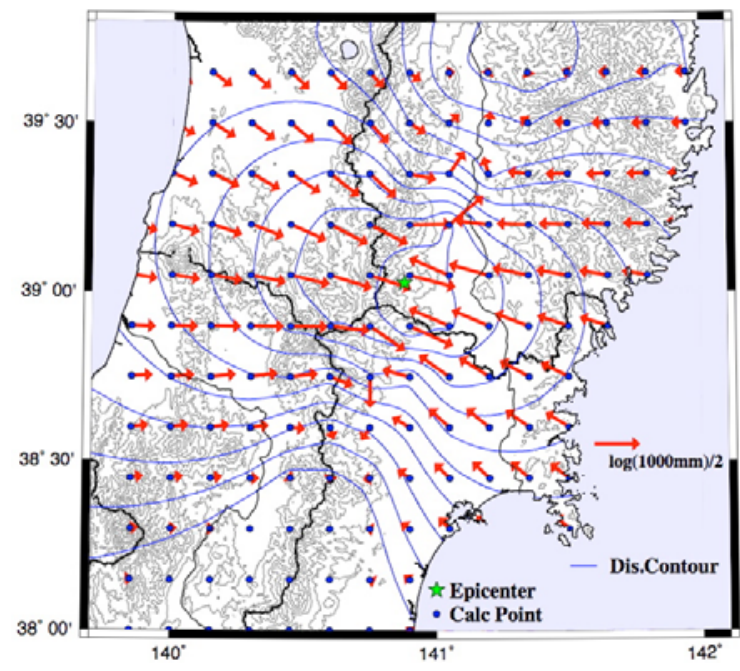

図12Coulombによる理論永久変位の分布 (水平方向)

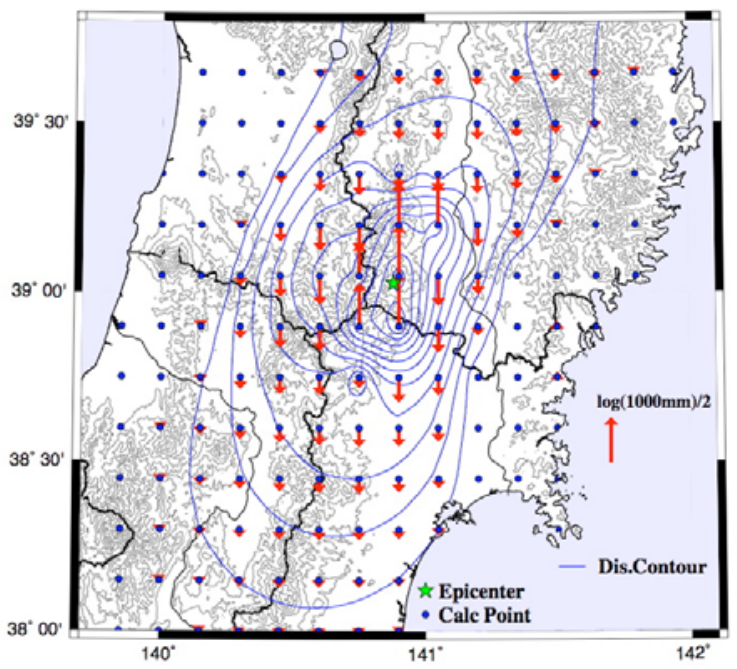

図13 Coulombによる理論永久変位の分布 (上下方向）

測による永久変位は理論的にも妥当であることが示唆される。

\section{5. 被害分布と強震動分布、永久変位分布との相関について}

2008年岩手・宮城内陸地震では強震記録が高密度で得られて各種の強震動パラメータの分布が詳細に 明らかになっていること、4学協会合同調査委員会の調査により構造物種別ごとの被害箇所分布が知られ ていること、さらにGEONETの観測により従来あまり調查されたことのない地盤の永久変位分布も水平 方向、上下方向の両方向にわたって明確になっていることを述べた。ここでは、同地震における被害の 特徵についての因果関係を明らかにするためこれらの各種パラメータ分布の相関について考察する。既 に述べたように、4学協会合同調查委員会の調查により土木関連施設と斜面被害に明確な分布の違いが観 察されたことから、本研究では二つの分布を計測震度、水平方向の永久変位分布および上下方向の永久 変位分布と比較する。

図14および図15に土木関連施設に関する被害分布の比較を示す。ここに、図14では永久変位分布は水 平方向の成分を対象としており、図15では上下方向の成分の永久変位を対象としている。同様な被害分 布の比較を斜面被害に対して行っているのが図16および図17である。これらの図で計測震度の分布はカ ラーイメージで表現されている。また、永久変位の分布は水平、上下それぞれの成分に対してべクトル とともにベクトルの大きさを等值線として与えている。さらに、これまでのマッピング処理と同様に震 央、標高のコンター、県境界線が参考にプロットされている。図14および図15での比較から土木関連施 設の被害は計測震度の分布とよく対応しており、土木関連の被害は計測震度でよく説明できることがわ かる。例えば、図14および図15の土木関係施設の被害では被害箇所の $100 \%$ が計測震度 4.7 以上の領域、 $75 \%$ 計測震度 5.7 以上の領域に存在している。同様に、水平、上下の両方向成分の永久変位分布も土木 関連施設の被害を説明できる。例えば、図14の土木関係施設の被害では被害箇所の $100 \%$ が水平永久変位

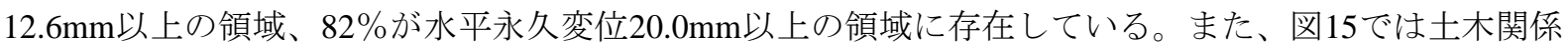

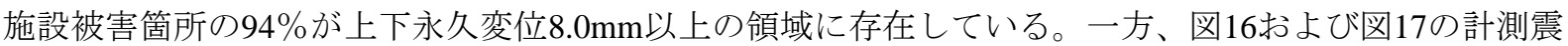
度の分布と斜面被害の分布には土木関連施設の分布ほどよい対応がみられない。これに対して、永久変 位の分布は水平、上下の両方向成分とも斜面被害の分布とよく整合している。特に、上下方向の成分の 永久変位分布はその等值線が斜面被害の領域をほぼ正確に包括するような形で分布しており、斜面被害 との対応に極めて高い整合性を示している。例えば、図 16 では斜面被害箇所の $82 \%$ が水平永久变位 $31.7 \mathrm{~mm}$ 以上の領域に存在するのに対して、図17では斜面被害箇所のほぼ $100 \%$ 年上下永久変位 $12.6 \mathrm{~mm}$ 以 上の領域にあり、しかも上下永久変位の絶対值のコンターは斜面被害分布を相似的に包含している。 


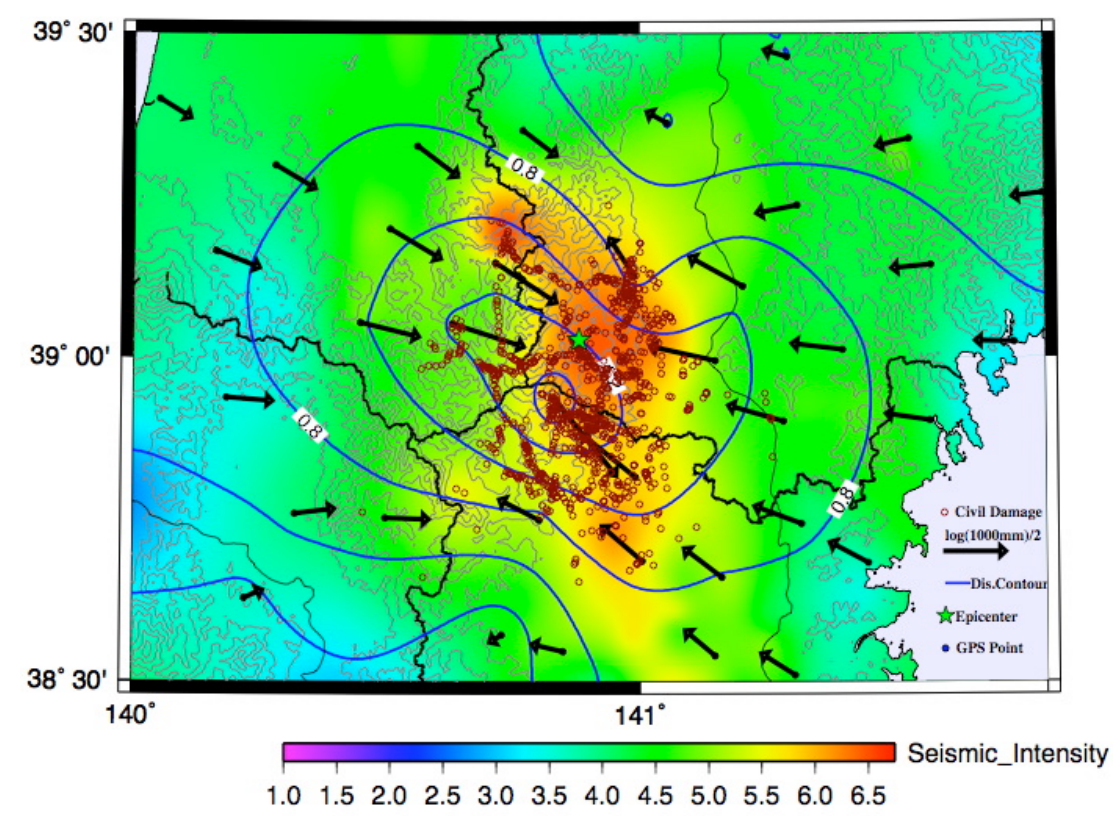

図14 土木関連施設の被害分布と計測震度、水平永久変位分布の比較

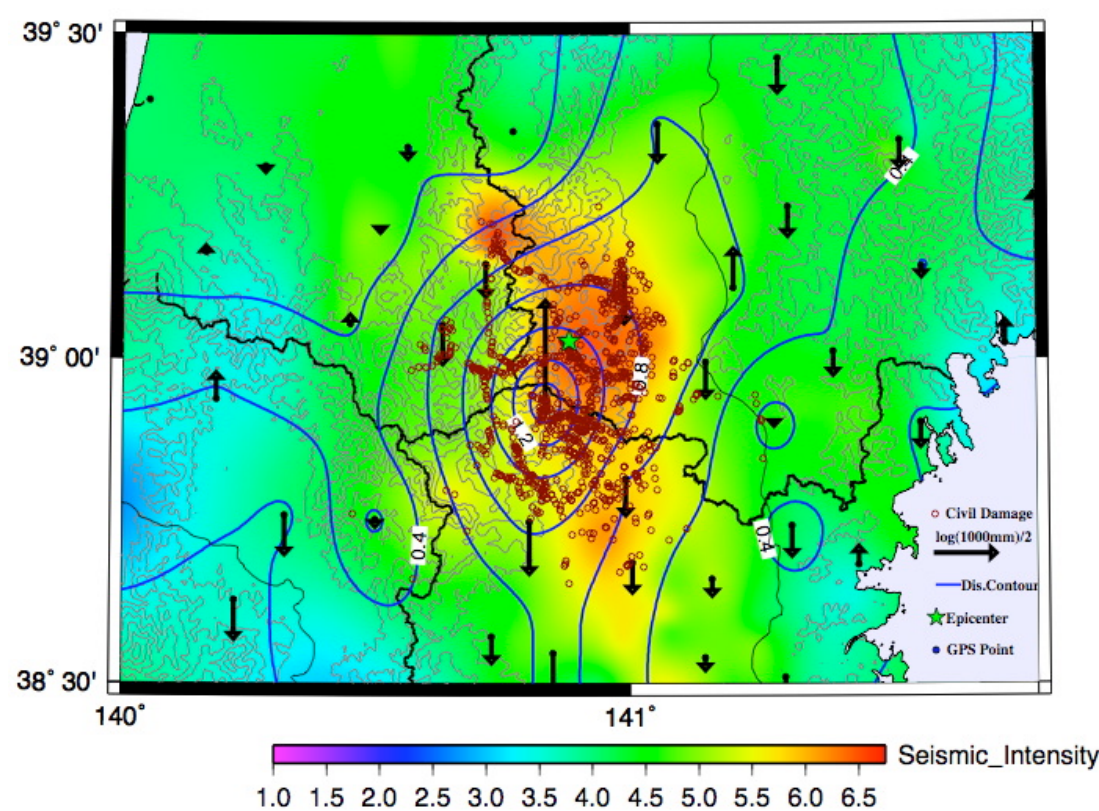

図15土木関連施設の被害分布と計測震度、上下永久变位分布の比較

\section{5. 斜面被害と永久変位との相関に関する定性的考察}

上述のように土木関連施設被害と斜面被害には異なる被害分布の様相が観察される。土木関連施設の 被害は計測震度の分布に相対的によく相関しており、斜面被害は逆に永久変位の分布との間に高い相関 が存在する傾向が得られた。土木関連施設は地盤斜面と異なり、地震動に対して質点系の特性をもって 応答すると考えられ、質点系の応答に関係の深い計測震度との間に高い相関をもったものと推定される。 一方、地盤斜面は連続体として地震動の影響を受けるので、質点系の応答特性とは異なる形で入力地震 動の影響を受けや寸いと考えられる。ここで、斜面被害と永久変位との間に高い相関が得られた理由に 


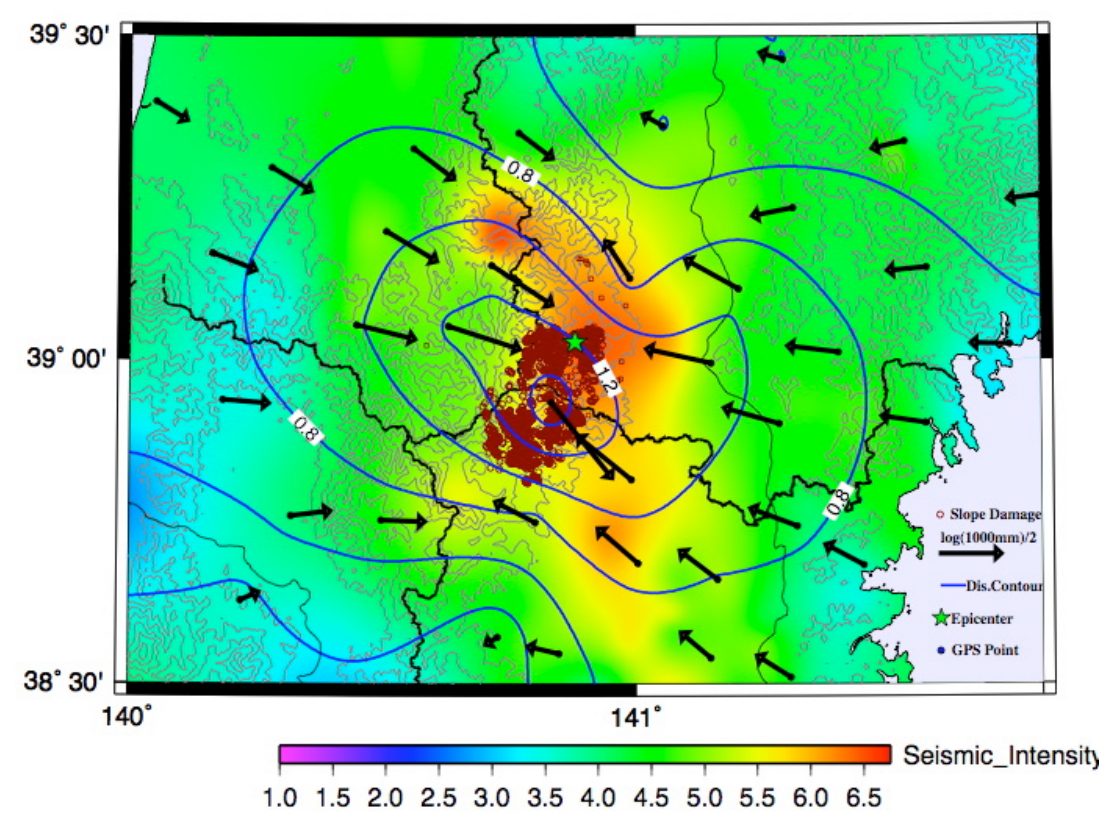

図16＼cjkstart斜面の被害分布と計測震度、水平永久变位分布の比較

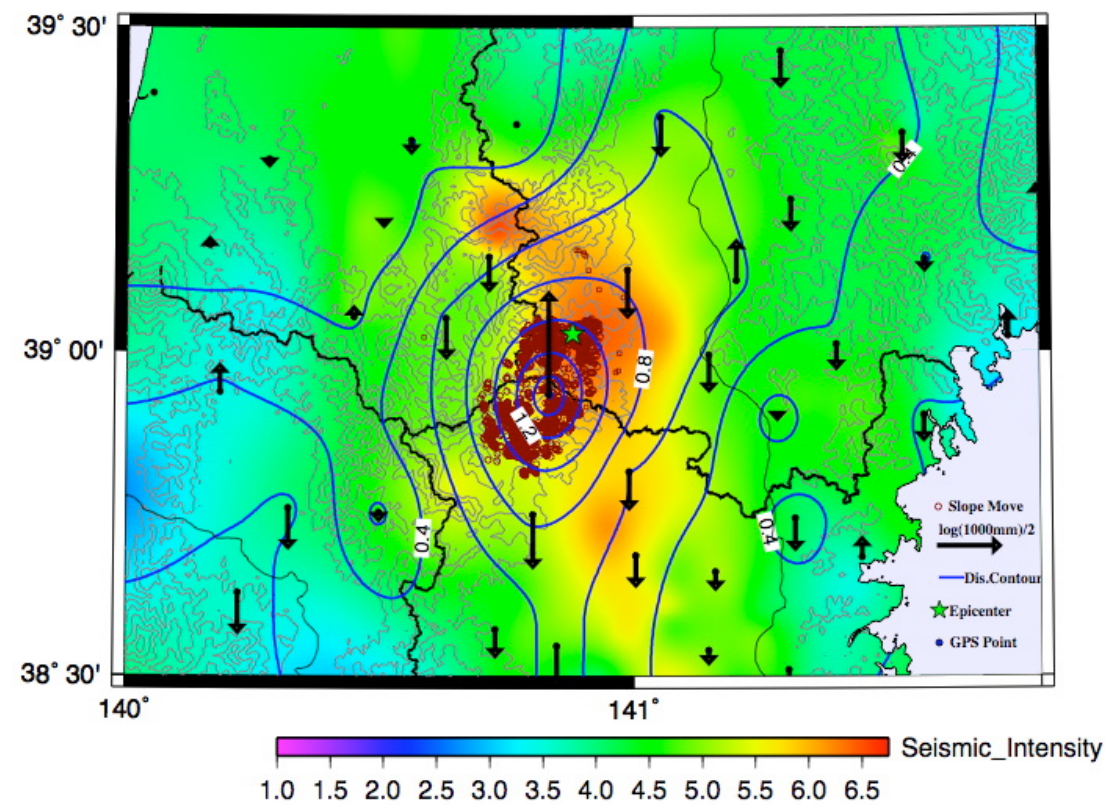

図17＼cjkstart斜面の被害分布と計測震度、上下永久变位分布の比較

\section{ついて定性的に考察してみる。}

考えられる斜面被害と永久変位との関係について定性的なメカニズムを表現したものが図18である。 連続体の表面の寸べりである斜面被害に最も関与する力学的なパラメータはひずみと考えられる。した がって、本研究も本来なら永久変位の分布ではなく、各種のひずみ成分を求めて、それらの分布と被害 分布との関係を対象とすべきである。ただし、原理的にはひずみ算定も可能であるが、GEONETのよう な低い密度の観測点による観測では精度よいひずみの算定は困難である。このような理由から本研究で は永久変位の考察に留めたものである。一方、周知のように、ひずみは変位の空間微分として与えられ るので、変位の絶対值が大きいこと自体、ひずみが大きいことに関与寸る度合いは強くなるとして大き 


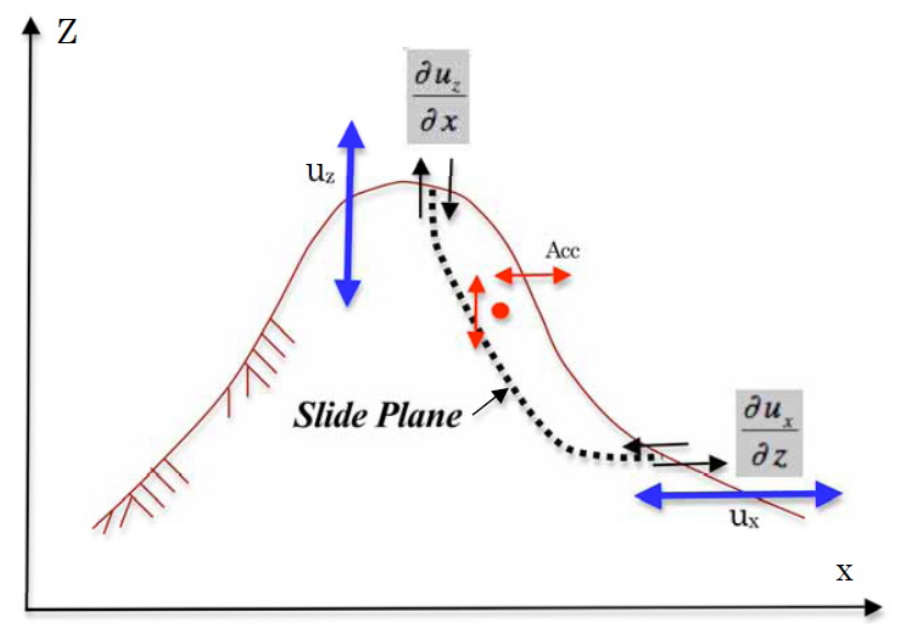

図18＼cjkstart斜面被害に及ぼす水平、上下方向の永久変位の影響の定性的説明
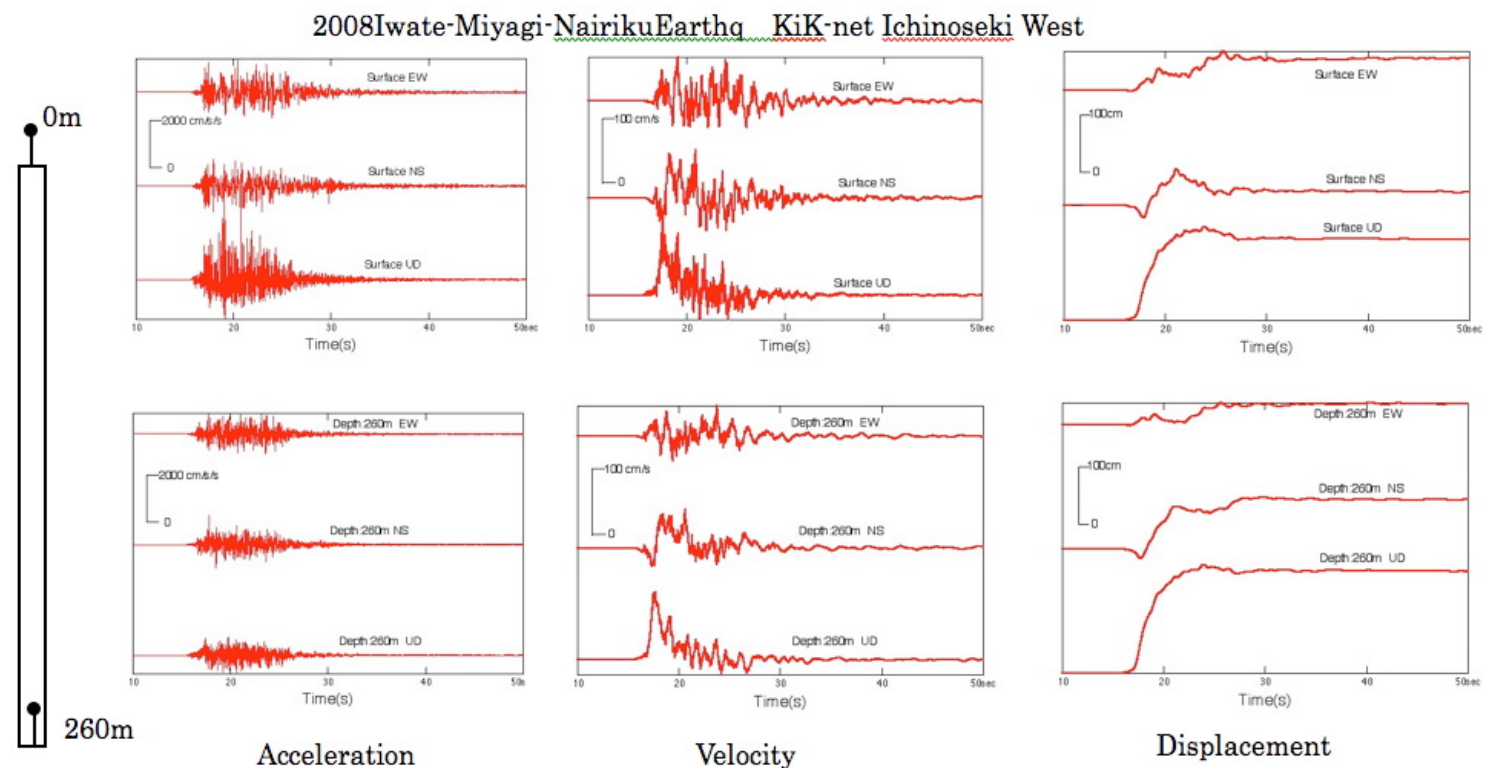

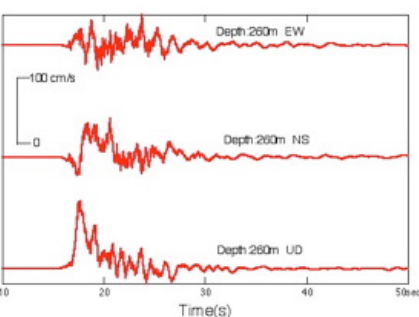

Velocity

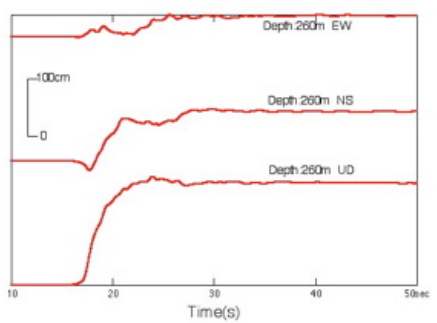

Displacement

図19 KiK-net一関西観測点の加速度記録からの速度、変位記録の算定

な誤りはないと考えられる。このような観点から図18を参考に想定される斜面被害に関する永久変位の 関与について述べる。

いま、水平方向成分の永久変位を $u_{x}$ 、上下方向の永久変位 $u_{z}$ とすると、それらの変位成分が大きいと き、その空間微分で与えられる二つのひずみ成分 $\partial u_{x} / \partial z$ 、および $\partial u_{z} / \partial x$ は図 18 に示すようにそれ ぞれ斜面の下端と上端で図示するような向きに発生する。これらのせん断ひずみ成分はその性質から図 18 に示すような潜在的なすべり面の発生に寄与寸ると考えられる。このようなせん断ひずみの発生によ り潜在的なすべり面が生成されると、地震動による加速度 Acc による慣性力が作用することによりすべ り面にそって斜面すべりが発生すると考えられる。以上が本研究での現段階における永久変位と斜面被 害との高い相関に関寸る定性的な解釈である。なお、ここでの説明は動的な変位地震動を用いて説明し ているが変位の時間変動と永久変位とには正の相関がある。一例として、図 2 の KiK-net 一関西観測点 における地表と地下の加速度記録を用いて数值積分で求めた速度、変位記録を示したのが図 19 である ${ }^{9)}$ 。 図 19 における変位記録を参照しても動的変位の最大值は永久変位とほぼ同程度の值を有することがわ かる。ここで、図 19 の KiK-net 観測点と図 8 で示した GEONET 観測点の栗駒 2 は水平距離で約 $8 \mathrm{~km}$ 程 
度はなれているが、各成分の永久変位の大きさは数值積分による算定と GPS による算定と算定方法は異 なっているものの両地点で值が整合している。

\section{6. むすび}

本論文では2008年岩手・宮城内陸地震は強震動の知見が極めて詳細に知られていること、4学協会合同 調査委員会により各種被害の地点がGISデータベースとして整理されていることに鑑みて、地震被害の 因果関係を明らかにするため被害分布と強震動分布の相関について考察した。被害のうち2008年岩手・ 宮城内陸地震の特徵として顕著であった斜面被害（斜面崩壊、地すべり、土石流など）は震央に対して 南部領域に偏在する傾向が観察された。本研究ではこの特徵を解くヒントを与えるものとして、強震記 録による強震動パラメータに加えて、従来地震被害の調査であまり利活用されてこなかったGPS技術を 駆使したGEONET観測データによる地盤の永久変位に着目した。これら被害地点のデータ、強震動パラ メータのデータおよびGEONETによる永久変位データの分布に関する相関の検討結果は以下のように まめられる。

(1) 土木関連施設と斜面被害には異なった分布傾向がみられた。前者は震央のまわりに均等に分布する 傾向があるのに対して、斜面被害は震央の南側に偏在して分布する。

（2）強震動パラメータの分布を整理した結果、最大加速度值の分布は余震分布に整合して震源断層を反 映したものとなっている。一方、計測震度は震源断層の形にプラスしてローカルサイトの影響も加味さ れた分布性状を示している。

(3) GEONETによる永久変位の解析から、2008年岩手・宮城内陸地震の発生により日本列島が震源断層を 挟んでほぼ東西方向に短縮している事実がみられた。これは水平方向の永久変位におけるべクトル分布 から明瞭に把握できる。また、上下方向の永久変位分布から、水平方向と上下方向では全く異なる変位 分布パターンが存在する。上下方向の永久変位分布から震源近傍を除き、広く地盤が沈下寸る永久変位 が上下方向に生じたこと、その大きさの分布パターンは水平方向の変位分布と異なり、震源断層の水平 面投影と相似形となる傾向を示している。これらの水平、鉛直の両方向の変形パターンは逆断層のパタ ーンに符号していることが震源断層の食い違いによる理論シミュレーションから確認された。

(4) 種別ごとの被害分布と強震動（特に計測震度）の分布、永久変位の分布の相関に関する検討から以 下のことが判明した。土木関連施設の被害は計測震度の分布とよく対応しており、土木関連の被害は計 測震度でよく説明できる。同椂に、水平、上下の両方向成分の永久変位分布も土木関連施設の被害と整 合している。一方、斜面被害での比較では、計測震度の分布は土木関連施設の分布ほどよい対応を示さ ない。これに対して、永久変位の分布は水平、上下の両方向成分ともそれらの絶対值が相対的に大きい 箇所で斜面被害の分布と重なる様相を呈している。特に、上下方向の成分の永久変位分布はその等值線 が斜面被害の領域をほぼ正確に包括するような形で分布しており、斜面被害との対忘に極めて高い整合 性がみられる。

(5) 斜面被害と永久変位との間に高い相関が得られた結果について定性的な解釈を加えた。ここでは、 永久変位の大きさがその空間微分である二つのひずみ成分の発生に関与するメカニズムについて言及し た。

ここで、与えられた結果は2008年岩手・宮城内陸地震の調査のみよるものであり、一種のケーススタ ディである。今後、多くの地震による被害調查をさらに積み重ねる必要があるのは言うまでもない。ま た、斜面被害については4学協会合同調査委員会の報告書の被害箘所などを被害規模の区別をしないで一 括処理しているが、さらに規模に応じた詳細な検討が必要と考えられる。ただし、そのような被害内容 の詳細とは別に、GEONETによる地震被害地点の推定は有力な一手段を提供するものと考えられ、今後、 地震工学の分野でも積極的に利活用することが望まれる。特に、GEONETのデータは近年1秒間ごとの リアルタイムな提供がなされるようになっていることに鑑み、そのリアルタイムの有効利用は地震工学 に多くの貢献をもたらすものと期待される。 
本論文の作成に当たっては、気象庁、各県震度情報ネットワーク、（独）防災科学研究所、国土地理 院などの多くの機関の提供するデータを利用させていただいた。これらの機関の関係者の日頃のご尽力 にお礼申し上げる。また、本論文では2008年岩手・宮城内陸地震の被害調査に関して4学協会合同調查委 員会のGISデータを利用させていただいた。これらの被害箇所に関するデータを提供された多くの機関 の関係者、およびそれらの被害箇所をGISデータとして整理された（株）テクノ長谷に感謝申し上げあ る。本論文の図作成にはマッピングソフトウエアGMT（Generic Mapping Tools） ${ }^{10)}$ を使用した。開発を 進めているP.Wessel とW.H.F. Smithの両氏に深甚なる謝意を表す。

\title{
参考文献
}

1) 気象庁: 2008 年 6 月 14 日0 08 時43 分ころの岩手県内陸南部の地震について、報道発表資料、 平成20年6月14日10時30分、 2008 年、pp.1-7.

2) 平成20年岩手 - 宮城内陸地震 4 学協会東北合同調査員会 : 平成20年岩手 - 宮城内陸地震災害調查報告 、2009 年、pp.1-500.

3）とうほく地盤情報システム運営協議会 : 地盤情報サイト「みちのくGIDAS」、 hhtps://tkkweb02.tohokukk.jp、2011年.

4) (独)防災科学研究所 : 高感度地震観測網Hi-net、/http://www.hinet.bosai.go.jp .

5) (独)防災科学研究所 : 基盤強震観測網KiK-net、/http://www.kik.bosai.go.jp .

6) 宮原伐折羅、野神頽、梅沢武、岩下知真子、川元智司：GPS 連続観測システム（GEONET）の解析 戦略（第 4版）から見た地款変動について、国土地理院時報、Vol.118、2009年、pp.31-36.

7) 遠田晋次、R.S. Stein、G.C.P. King：ディスロケーションソフトウエア「Coulomb」紹介、活断層研 究、21号、2002年、pp.25-32.

8) 東京大学地震研究所強震動グループ: 2008 年岩手・宮城内陸地震 一震源過程一、地震研究所ホーム ページ版<40; 3483>、2008 年、pp.1-2.

9) 佐藤拓也、神山 眞、松川忠司 : 強震加速度記録による永久变位の算定とその考察、平成22年度土木 学会東北支部技術研究発表会、DVD、2011年、pp. 1-2.

10) Wessel, P. and W.H.F. Smith : The Generic Mapping Tools Technical Reference and Cookbook, Version 3.3, 1999, pp. 132.

\section{COMPARISONS BETWEEN DAMAGES AND MOTION PARAMETERS}

\section{CAUSED BY THE 2008 IWAT-MIYAGI NAIRIKU EARTHQUAKE}

\author{
KAMIYAMA Makoto ${ }^{1)}$, MATSUKAWA Tadashi ${ }^{2)}$ and ANAZAWA Masahiro ${ }^{3)}$
}

1) Member, Professor, Tohoku Institute of Technology, Dr. Eng.

2) Associate, Tohoku Institute of Technology

3) Associate Professor, Associate, Dr. Science

ABSTRACT
The 2008 Iwate-Miyagi-Nairiku Earthquake, which hit Iwate, Miyagi and Akita Prefectures in Japan with a 
JMA magnitude of 7.2 on June 14, 2008, caused various kinds of geotechnical damages in the epicentral area. This paper describes the relations between the permanent displacements of ground and damages of soils mainly including slope failure caused by the earthquake. The permanent displacements of ground were obtained using both the position data of the GEONET system operated with aid of GPS and the displacement records numerically estimated from strong ground motions. It is concluded that the permanent displacement of ground can explain well the geotechnical damages occurred during the earthquake rather than strong motion data such as acceleration amplitude and seismic intensity scale.

Key Words: Earthquake, Permanent Displacement, GPS, Strong Motion Records, Slope damage 